\title{
Penerapan Model Pembelajaran Number Head Together: Upaya Meningkatan Keterampilan Menulis Esai Mahasiswa
}

\author{
Sri Widayati ${ }^{1}$, Yasinta Mahendra ${ }^{2}$, Rohmani $^{3}$ \\ Universitas Muhammadiyah Kotabumi

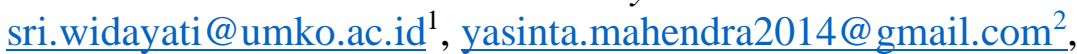 \\ rohman.orgos@gmail.com ${ }^{3}$
}

DOI: https://doi.org/10.32528/bb.v6i2.5999

First received: 12-10-2021 Final proof received: 28-10-2021

\begin{abstract}
ABSTRAK
Masalah dalam penelitian ini ialah masih relatif rendahnya kemampuan mahasiswa PBSI Universitas Muhammadiyah Kotabumi untuk menulis esai, sehingga perlu digunakan metode pembelajaran Number Head Together (NHT) dalam proses pembelajaran guna membantu meningkatkan hasil kemampuan mahasiswa dalam menulis esai. Tujuan penelitian ini ialah untuk memberikan gambaran peningkatan kemampuan menulis esai pada mahasiswa PBSI Universitas Muhamadiyah Kotabumi setelah dosen memakai pembelajaran model Number Head Together (NHT). Metode yang digunakan ialah deskriptif kualitatif. Data yang didapatkan merupakan hasil dari nontes, yaitu melalui proses observasi, wawancara kepada mahasiswa, serta melakukan teknik dokumentasi berupa hasil pengujian prasiklus. Berdasarkan data penelitian yang telah diperoleh, didapati hasil bahwa terdapat peningkatan yang cukup signifikan terhadap kemampuan menulis esai pada mahasiswa PBSI Universitas Muhammadiyah Kotabumi setelah mengikuti mata kuliah menulis esai dengan menggunakan model pembelajaran NHT.
\end{abstract}

Kata kunci: model pembelajaran; NHT; keterampilan menulis; menulis esai

\begin{abstract}
The problem in this research is the low ability of PBSI students at Muhammadiyah University of Kotabumi to write essays, so it is necessary to use the Number Head Together (NHT) learning method in the learning process to help improve student essay writing skills. The purpose of this study was to provide an overview of improving essay writing skills for PBSI students at Muhamadiyah University Kotabumi after using the Number Head Together (NHT) learning model. The method used is descriptive qualitative. The data obtained is the result of the non-test, namely through the process of observation, interviews with students, and performing documentation techniques in the form of pre-cycle test results. Based on the research data that has been obtained, the results obtained are that there is a significant increase in the ability to write essays in PBSI
\end{abstract}


students at Muhammadiyah University of Kotabumi after taking essay writing courses using the NHT learning model.

Keywords: learning model; NHT; writing skills; writing essays

\section{PENDAHULUAN}

Menulis adalah proses konstruksi dan merupakan salah satu keterampilan paling sulit yang harus dipelajari siswa (Núñez Tapia, 2012). Kegiatan menulis pada hakikatnya adalah sebuah proses daya kreativitas berpikir seorang individu untuk dapat menuangkan gagasan, ide yang dimilikinya serta dapat mengungkapkannya secara tidak langsung, tetapi melalui tulisan. Seperti yang telah diketahui bersama bahwasanya tidak semua orang memiliki kemampuan untuk mengungkapkan ide, gagasan secara langsung. Oleh karena itu, kemampuan menulis sangat diperlukan. Keterampilan menulis merupakan aspek kebahasaan yang sangat diperlukan oleh manusia, terutama mahasiswa. Tulisan yang diungkapkan oleh seorang penulis, tentunya memiliki tujuan tertentu. Misalnya, tujuan untuk memberitahukan mengenai suatu hal yang bersifat pribadi/rahasia, atau bermaksud meyakinkan orang lain. Bahkan, dapat ke lawan jenis dengan tujuan memikat hati lewat tulisan. Bisa juga tulisan yang dibuat seseorang bertujuan hanya sekadar menghibur dirinya sendiri dan orang lain. Hasil dari pemikiran kreatif yang bersumber dari individu yang dituangkan lewat bahasa tertulis itulah yang kemudian disebut karangan/tulisan.

Kegiatan menulis pada dasarnya merupakan bagian yang biasanya menjadi satu kesatuan yang didapatkan lewat proses belajar yang dialami mahasiswa, terutama di tempat mereka menempuh jalur pendidikan formal. Tidak dapat dimungkiri hampir semua mata pelajaran, baik di sekolah dari tingkat yang paling dasar maupun tingkat yang paling tinggi pasti tidak lepas dari kegiatan menulis.

Tujuan pembelajaran menulis di Prodi PBSI UMKO, yaitu agar peserta didik dalam hal ini mahasiswa dapat dengan leluasa secara kreatif menyampaikan gagasan/ide, pendapat, serta pengetahuan yang dimilikinya secara tertulis tanpa takut salah. Dengan memiliki kemampuan menulis yang baik, diharapkan mahasiswa ke depannya dapat dengan mudah mengembangkan kreativitas kebahasaan yang mereka miliki dan menyalurkannya untuk dipergunakan di dalam kehidupan dalam bermasyarakat maupun lingkungan kerja yang nantinya mereka inginkan.

Pada dasarnya aktivitas menulis ialah suatu hal yang dengan mudah dapat dilakukan oleh seseorang/individu. Kegiatan menulis pada tiap-tiap jenjang satuan pendidikan dari TK hingga Perguruan Tinggi selalu diajarkan. Namun, kemampuan yang diperoleh seseorang tersebut tidaklah sama. Hal ini terjadi karena dipengaruhi oleh berbagai hal. Tarigan, (2013) mengemukakan jika keterampilan menulis ialah salah satu bagian/bentuk dari kesatuan-kesatuan berekspresi yang disampaikan lewat aspek kebahasaan. Selanjutnya Tarigan mengemukakan bahwa kegiatan menulis juga sebagai salah satu bentuk kegiatan seni. Hal itu dikarenakan dalam kegiatan menulis, seseorang melukiskan/menggambarkan kembali lambang, bentuk atau grafik yang fungsinya dapat dengan jelas menggambarkan suatu bahasa. Semula lambang tersebut sulit untuk 
diartikan oleh orang lain, tetapi pada akhirnya makna dalam tulisan yang sulit tersebut mampu/bisa dipahami dan dimengerti oleh masyarakat. Hal inilah yang menjadi alasan mengapa kegiatan menulis dikatakan sebagai salah satu aspek penting yang perlu dikuasai seseorang dalam proses berkomunikasi/ penyampaian pesan dalam kehidupan bermasyarakat.

Berdasarkan pemaparan di atas dapat dikatakan bahwa kegiatan menulis ialah suatu kegiatan yang tidak dapat dipisahkan dari proses belajar-mengajar. Hal ini disebabkan proses menulis bukanlah hal yang mudah untuk dilakukan oleh mahasiswa. Kegiatan menulis memerlukan waktu yang lama jika seseorang ingin menghasilkan tulisan yang baik. Dalam proses menulis tidak hanya diperlukan tulisan yang rapi dan indah, tetapi juga diperlukan ketelitian, dan kreativitas. Semuanya itu tentunya bersumber dari dalam diri mahasiswa. Dengan demikian, untuk dapat menghasilkan tulisan-tulisan yang mengandung makna dan dapat dimengerti oleh orang lain atau pembaca diperlukan satu kesatuan syarat penulisan yang harus dipenuhi oleh mahasiswa.

Ada berbagai macam jenis keterampilan menulis, salah satunya menulis karangan esai. Dalam proses pembelajaran menulis/membuat karangan esai, mahasiswa diharapkan memiliki kemampuan untuk mengembangkan ide-ide yang mereka miliki. Dalam proses menulis esai diperlukan kecermatan untuk membaca situasi serta kondisi lingkungan sekitar. Misalnya, hal apa saja yang menarik, isu-isu apa yang sedang hangat berkembang sehingga mereka dapat menuangkan gagasan ke dalam tulisan esai yang mereka buat. Dengan demikian, esai yang mereka hasilkan nantinya akan terlihat baik dan menjadi lebih menarik untuk dibaca oleh pembaca.

Kosasih, (2012) mengemukakan bahwa esai merupakan sebuah tulisan/paragraf yang dibuat dengan tujuan untuk memengaruhi emosional serta psikis pembacanya. Dalam membuat sebuah esai, penulis memerlukan kelengkapan data serta contoh konkret atau relevan. Hal tersebut berguna untuk memengaruhi pembaca secara meyakinkan dengan argumen yang diberikan. Penjelasan Kosasih tersebut menunjukkan bahwa tulisan esai dapat memengaruhi atau mengajak pembacanya untuk ikut berargumen yang sama dengan penulisnya. Esai juga memberikan keseragaman sudut pandang seperti yang dikehendaki penulis, serta secara tidak langsung memaksa pembaca untuk memenuhi apa yang menjadi kehendak penulisnya. Jadi, berdasarkan pendapat Kosasih tersebut dapat disimpulkan bahwa dalam membuat sebuah esai, mahasiswa tentunya diwajibkan untuk memiliki skill/kemampuan untuk mengolah data/informasi yang mereka miliki.

Berdasarkan hasil observasi awal yang dilakukan melalui wawancara dan prasiklus pada mahasiswa PBSI Universitas Muhammadiyah Kotabumi didapatkan data bahwa kemampuan menulis esai masih rendah. Hal ini disebabkan banyak mahasiswa mengalami kesulitan dalam menulis esai. Rata-rata kesulitan yang mereka alami, yaitu dalam menentukan ide/gagasan dan membuat paragraf yang berisi argumen si penulis. Kesulitan lain yang dihadapi oleh mahasiswa, yaitu minimnya kosa kata dan pengetahuan tentang topik bahasan esai yang akan mereka buat. Rata-rata dari mereka belum banyak mengetahui tentang esai, bagaimana menulisnya sehingga mereka belum dapat menguasai teknik penulisan esai. Inilah yang menyebabkan mereka kesulitan untuk merangkai kata-kata yang tepat ke dalam paragraf esai. Hal itu terjadi salah satunya 
disebabkan mahasiswa secara menyeluruh belum memahami tujuan dan manfaat memalis esai. Selain itu, menulis esai bagi sebagian besar mahasiswa dianggap sebagai kegiatan yang rumit dan membosankan.

Penggunaan metode pembelajaran menulis esai pun masih konvensional atau satu arah sehingga hasilnya belum maksimal. Dalam hal ini pengajar bertindak sebagai perencana, pelaksana, dan pengembang kurikulum untuk kelas dan kuliah yang diampunya. Oleh karena itu, diperlukan tipe metode ajar yang lebih banyak dan beragam sehingga mahasiswa dapat berperan lebih aktif dalam proses pembelajaran dan dapat menumbuhkan potensi yang dimilikinya khususnya dalam kemampuan menulis esai.

Model pembelajaran yang diterapkan dosen dalam proses pembelajaran semestinya mengacu pada sistem pendidikan yang lebih menekankan proses berpikir dan memperbanyak latihan. Dengan demikian, proses pembelajaran menjadi aktif, bersifat kooperatif, serta menghormati perbedaan yang ada dalam kehidupan masyarakat yang multikultural. Pembelajaran kooperatif menjadikan mahasiswa satu dengan yang lainnya menjadi saling ketergantungan secara positif. Dengan kata lain, pembelajaran menggunakan model kooperatif menjadikan hubungan simbiosis mutualisme di antara mahasiswa agar mencapai tujuan pembelajaran seperti apa yang diinginkan. Dengan interaksi belajar seperti ini diharapkan proses transfer ilmu pengetahuan berjalan lebih efektif. Mahasiswa menjadi lebih termotivasi dan percaya diri untuk mengemukakan pendapat yang ada di dalam dirinya.

Model pembelajaran kooperatif dapat membantu mahasiswa mengemukakan pendapat dan jika terjadi perbedaan pendapat antarmahasiswa, perbedaan tersebut justru menjadi bahan pembelajaran yang menarik. Hal tersebut memungkinkan seluruh mahasiswa dapat menguasai materi yang sama dan pada tingkat penguasaan materi yang relatif sama dan sejajar. Dengan kata lain, kemampuan mahasiwa setelah mengikuti pembelajaran menjadi heterogen. Ada beberapa jenis model/tipe pembelajaran kooperatif di antara beberapa jenis ini masing-masing memiliki kelebihan dan kekurangan. Hal ini bergantung pada jenis pembelajaran yang akan digunakan, tipe pembelajaran kooperatif tersebut antara lain, yaitu 1) Student Teams Achievement Division (STAD), 2) Jigsaw, 3) Team Games Tournament (TGT), 4) Team Assisted Individualization (TAI), 5) Numbered Head Together (NHT), 6) Think Pair Share (TPS) dan 7) Group Investigation (Grup Investigasi).

Berdasarkan karakteristik mahasiswa dan kelebihan serta kekurangan masingmasing dari pembelajaraan kooperatif, pada penelitian ini akan digunakan pembelajaran kooperatif dengan model NHT. Penggunaan model pembelajaran tersebut lebih memungkinkan mahasiswa untuk lebih aktif dan bertanggung jawab penuh dalam memahami materi esai yang nantinya diberikan oleh dosen. Hal ini seperti yang hasil penelitian yang dilakukan oleh Rahmawati et al., (2021) bahwa pembelajaran model NHT memberikan hasil belajar yang lebih baik dibandingkan dengan model pembelajaran konvensional dan motivasi siswa dapat ditingkatkan melalui NHT dibandingkan dengan pembelajaran langsung. Penggunaan model NHT diharapkan mahasiswa dapat dengan leluasa dan mendapatkan hasil yang maksimal mengerjakan tugas menulis esai, baik yang mereka lakukan secara berkelompok maupun secara individual. Dalam proses 
pembelajaran menulis esai di kelas, semua mahasiswa dianggap memiliki kemampuan yang sama, dan dosen tidak lagi mendominasi proses pembelajaran yang berlangsung. Dosen hanya bertindak sebagai fasilitator dalam kegiatan diskusi yang dilakukan oleh mahasiswa itu sendiri selama pembelajaran berlangsung. Mahasiswa dilibatkan secara penuh sehingga mereka memeroleh pengetahuan yang sama dan pengalaman belajarnya secara menyeluruh dan merata.

Dalam proses transfer ilmu dengan menggunakan metode kooperatif tipe NHT, mahasiswa secara aktif bekerja dalam tim. Ketua tim memiliki tanggung jawab penuh terhadap tugas yang diberi dosen kepada kelompoknya. Nantinya kelompok itulah yang akan menjabarkan keseluruhan materi pada teman-temanya saat proses pembelajaran. Dalam hal ini mahasiswa akan terbagi menjadi beberapa kelompok sehingga dalam satu kelompok memiliki kemampuan heterogen atau tidak sama. Mahasiswa yang berkemampuan rendah dapat bertanya dan berdiskusi dengan rekan mahasiswa berkemampuan tinggi. Selanjutnya mahasiswa yang memiliki kemampuan tinggi dapat lebih memahami apa yang akan mereka paparkan pada teman sejawatnya dan memberikan bantuan pada mahasiswa yang berkemampuan rendah.

Proses kegiatan menulis esai pada mahasiswa dapat ditingkatkan jika seluruh pengajar dalam hal ini dosen dapat menggunakan metode yang tepat dalam proses pembelajaran (Spanou \& Zafiri, 2019). Selama proses belajar mengajar berlangsung, penggunaan metode pembelajaran yang digunakan dosen akan sangat membantu dan berpengaruh pada keefektifan proses pembelajaran yang dilakukan. Dengan demikian, pemberian metode belajar yang tepat akan berpengaruh dan memudahkan dosen untuk menyampaikan pesan serta isi materi pada saat kegiatan belajar berlangsung.

Sebenarnya terdapat berbagai cara/metode belajar yang dapat digunakan oleh para pendidik dalam hal ini dosen untuk meningkatkan/menambah kemampuan keterampilan mahasiswa dalam hal menulis esai bagi peserta didiknya. Salah satu metode yang dapat digunakan, yaitu dengan cara menciptakan inovasi dalam mengajar yang dibuat oleh dosen, yaitu dengan model pembelajaran Number Head Together (NHT). Penelitian tentang model pembelajaran NHT sudah banyak dilakukan oleh peneliti terdahulu diantaranya (Islami et al., 2021; Wahyuni, 2019; Zahra et al., 2021). Model ini menuntut kerja sama antar mahasiswa dengan teman sejawatnya atau sesama kelompoknya dalam belajar.

Dengan model NHT, mahasiswa UMKO Prodi PBSI diberikan tugas oleh dosen untuk menulis sebuah esai dengan tema yang telah ditentukan. Kemudian mahasiswa diminta untuk berpikir serta melakukan kerja sama dengan teman sejawat dengan metode pembagian NHT. Dengan model NHT, mahasiswa dibagi berdasarkan nomor yang didapat bersama dengan pasangan atau kelompoknya. Selanjutnya mahasiswa menulis sebuah esai dengan tema yang mereka dapat dari dosen pengampu mata kuliah. Setelah mahasiswa mendapat tema esai, mereka mendiskusikan tema tersebut dan menulisnya ke dalam sebuah esai. Setelah selesai menulis esai, secara tim/berkelompok mereka membacakan hasil esai yang mereka buat kepada teman yang lainnya yang berbeda kelompok. Dengan metode pembelajaran seperti ini tentunya akan membuat mahasiswa 
mempunyai rasa sosial yang tinggi dan memiliki pemikiran dengan daya kreativitas yang tinggi

\section{METODE PENELITIAN}

Penelitian ini merupakan penelitian tindakan kelas. Prosedur pengembangan penelitian dimulai dengan membuat rencana. Kemudian dilanjutkan dengan realisasi tindakan, observasi dan evaluasi sedangkan refleksi berada pada tahap akhir. Penelitian tindakan kelas merupakan suatu cara yang dilakukan oleh pendidik guna memperbaiki layanan Pendidikan di kelas (Hanifah, 2014). Adapun target yang diinginkan dalam penelitian Tindakan kelas adalah dampak yang positif (Purnomo, 2011).

\section{Desain Penelitian}

Pada penelitian ini digunakan dua tahapan/siklus. Setiap tahapan terdiri dari beberapa langkah. Namun, sebelum siklus I dilakukan, dosen melaksanakan prasiklus. Setelah tahap prasiklus, dilakukan pengambilan data pada siklus pertama (I), setelah data dari siklus I diperoleh, langkah selanjutnya ialah analisis tahap 1. Setelah data analisis tahap I diperoleh, tahapan selanjutnya ialah pengambilan data pada siklus kedua (II).

Setiap siklus yang dilalui terdiri dari dua tahapan. Tahapan yang pertama, yaitu perencanaan, lalu tahapan yang kedua ialah tindakan. Prasiklus yang dilakukan pada mahasiswa bertujuan untuk mengetahui data awal kemampuan mahasiswa dalam menulis esai sebelum menerapkan model pembelajaran NHT. Data yang didapatkan dari proses prasiklus nantinya akan digunakan sebagai dasar pelaksanaan siklus I (pertama). Perolehan data dari proses tindakan yang telah dilakukan pada siklus I nantinya akan digunakan sebagai refleksi/sebagai dasar tindak lanjut untuk melaksanakan proses tindakan pada siklus II.

Selanjutnya hasil dari tindakan dari masing-masing siklus yang telah diperoleh lewat hasil penelitian digunakan untuk mengetahui ada/tidaknya perubahan kemampuan menulis esai pada mahasiswa setelah dosen menerapkan model pembelajaran NHT.

\section{Tempat dan Waktu Penelitian}

Tempat pelaksanaan dalam penelitian ini ialah Universitas Muhammadiyah Kotabumi. Waktu penelitian, semester ganjil tahun akademik 2021/2022

\section{Subjek dan Objek Penelitian}

Subjek dalam penelitian ini ialah mahasiswa semester V Program Studi PBSI yang berjumlah 40 mahasiswa. Kemudian objeknya ialah penerapan model belajar Number Head Together (NHT) dalam meningkatkan kemampuan keterampilan menulis esai pada mahasiswa Pendidikan Bahasa dan Sastra Indonesia Universitas Muhammadiyah Kotabumi.

\section{Populasi dan Sampel}

Sugiyono, (2016) menyatakan yang dimaksud dengan istilah populasi ialah suatu wilayah yang bersifat generalisasi/umum yang terdiri dari suatu objek serta subjek dan memiliki kualitas dengan ciri/karakter tertentu yang akan ditetapkan oleh peneliti itu 
sendiri. Populasi dalam penelitian ini ialah mahasiswa PBSI Universitas Muhammadiyah semester V (ganjil) tahun akademik 2021/2022.

\section{Instrumen Penelitian}

Menurut Widoyoko, (2016) instrumen penelitian ialah alat yang dipakai untuk membantu peneliti mengumpulkan data penelitian dengan cara melakukan pengukuran. Dalam penelitian ini instrumen yang digunakan ialah instrumen penilaian hasil tes menulis esai yang terdiri dari 5 poin ketercapaian menulis esai.

\section{Teknik Pengumpulan Data}

Teknik pengumpulan data ialah kegiatan yang dilaksanakan peneliti guna mendapatkan data berkaitan dengan hipotesis . Adapun teknik yang dipakai ialah teknik tes menulis esai. Hasil tes tersebut lalu dipakai untuk mengetahui kemampuan mahasiswa dalam menulis esai setelah dosen melakukan pembelajaran dengan model pembelajaran Number Head Together (NHT).

\section{Teknik Analisis Data}

Analisis data ialah metode yang dipakai dalam proses mengolah data yang sebelumnya telah didapat berdasarkan penelitian yang telah dilaksanakan. Adapun teknik analisis data yang dipakai dalam penelitian ini ialah teknik deskripsi kualitatif dengan mengolah hasil data yang diperoleh ke dalam bentuk kalimat bukan berupa angka (Rijali, 2019).

\section{PEMBAHASAN}

Hasil tes pada penelitian ini mengacu pada hasil perolehan skor yang telah dicapai oleh mahasiswa dalam tes menulis esai. Adapun penilaian terdiri dari lima aspek, yaitu 1) penilaian ide dan argumentasi penulis, 2) penilaian bahasa yang digunakan dan kerapian penulisan, 3) penilaian dari aspek ketajaman analisis permasalahan, 4) penilaian aspek kemampuan menguraikan faktor penyebab dengan argumen yang ilmiah tentang topik permasalahan, dan 5) terakhir adalah penilaian aspek kemampuan menghubungkan masalah dengan solusi yang diberikan. Hasil penilaian dari lima aspek, selanjutnya dikumpulkan menjadi satu guna memeroleh nilai atau hasil akhir terhadap tes menulis esai. Hal seperti ini dilakukan berulang pada setiap siklus, dimulai dari sebelum siklus atau prasiklus, berlanjut pada siklus I, lalu ke tahap siklus ke-II.

Berikut daftar/tabel perbandingan hasil tes menulis esai mahasiswa dari prasiklus, siklus I, dan siklus II. 
Tabel 1 Perbandingan Hasil Perolehan Menulis Esai Mahasiswa

\begin{tabular}{lccc}
\hline Interval & Prasiklus & Siklus 1 & Siklus II \\
\hline Sangat Tinggi (100) & 0 & 2 & 10 \\
\hline Tinggi (80-90) & 6 & 10 & 18 \\
\hline Sedang (70-79) & 14 & 20 & 10 \\
\hline Rendah (65-69) & 15 & 8 & 2 \\
\hline $\begin{array}{l}\text { Sangat Rendah (kurang dari } \\
\text { 65) }\end{array}$ & 5 & 0 & 0 \\
\hline \multicolumn{1}{c}{ Jumlah mahasiswa } & 40 & 40 & 40 \\
\hline
\end{tabular}

Berdasarkan data dari tabel di atas, hasil pengukuran peningkatan kemampuan menulis esai pada mahasiswa PBSI UMKO dimulai dari prasiklus, setelah itu masuk kepada siklus I. Setelah hasil siklus I diperoleh nilainya maka berlanjut pada siklus kedua II. Selanjutnya setelah didapati hasil dari pengukuran yang dilakukan pada siklus II, terlihat bahwa kemampuan menulis esai di masing-masing aspek mengalami peningkatan yang cukup signifikan. Hasil tes menulis esai mahasiswa PBSI yang dimulai dari prasiklus mendapatkan nilai rata-rata kurang dari 65 dengan kategori/penilaian sangat rendah. Data tersebut dapat dilihat berdasarkan acuan rentang nilai yang telah ditentukan sebelumnya. Penilaian ini didapat berdasarkan penilaian yang telah dilakukan terhadap mahasiswa PBSI UMKO yang berpatokan pada lima aspek yang telah disebutkan di atas.

Adapun penjabaran dari masing-masing aspek penilaian ialah sebagai berikut.

a. Penilaian aspek ide dan argumentasi penulis dengan skor penilaian sebesar $15 \%$

b. Penilaian bahasa yang digunakan dan kerapian penulisan dengan skor penilaian sebesar $15 \%$

c. Penilaian aspek ketajaman analisis permasalahan dengan skor penilaian sebesar $20 \%$

d. Penilaian aspek kemampuan menguraikan faktor penyebab dengan argumen yang ilmiah tentang topik permasalahan dengan skor penilaian sebesar $25 \%$ dan

e. Penilaian aspek kemampuan menghubungkan masalah dengan solusi yang diberikan penulis dengan skor penilaian sebesar $25 \%$

Beberapa hasil dari tes siklus akan dijabarkan sebagai berikut. Hasil tes menulis esai mahasiswa PBSI pada siklus I diperoleh nilai rata-rata sebesar 37,7\%. Nilai tersebut dikategorikan 'sedang' dengan rentang nilai 70-79. Nilai itu diperoleh dari beberapa aspek penilaian yang dilakukan dengan pengukuran. Aspek penilaian yang dilakukan mengikuti 5 aspek penilaian isi esai mahasiswa yang telah ditentukan sebelumnya.

Penilaian pada siklus ke II mahasiswa juga memeroleh peningkatan nilai yaitu dari rentang Dari penjabaran perolehan hasil ini dapat diketahui dan ditarik simpulan bahwa dari hasil tes terdapat peningkatan kemampuan menulis esai yang dimulai dari prasiklus sampai siklus I hingga akhirnya perolehan persentase mencapai jumlah 17, 67\%.

Berdasar hasil tes menulis esai yang telah dilakukan pada siklus II terhadap mahasiswa PBSI didapatkan nilai rata-rata nilai 80-90. Bahkan, ada 10 orang 
mahasiswa memperoleh nilai tinggi dengan rentang nilai 9-100. Dengan demikian, secara keseluruhan hasil menulis esai mahasiswa mengalami peningkatan sebanyak 45,66\% jika dilihat dari setiap siklus yang dijalani. Dari hasil tes ini dapat diketahui bahwa terdapat peningkatan kemampuan menulis esai mahasiswa dimulai dari prasiklus, lalu dilanjutkan ke tahap siklus I mengalami peningkatan perolehan nilai mencapai jumlah hingga $36,7 \%$.

Dengan demikian dari hasil tes dapat diketahui bahwa terdapat peningkatan kemampuan menulis esai pada mahasiswa PBSI Universitas Muhammadiyah Kotabumi dari mulai prasiklus, siklus I ke siklus II mengalami kenaikan hingga 45,66\%. Hal ini menunjukkan bahwa penerapan model pembelajaran Number Head Together (NHT) dalam pembelajaran menulis esai dapat meningkatkan kemampuan keterampilan mahasiswa semester V PBSI Universitas Muhammadiyah Kotabumi dalam menulis esai pada.

Berdasarkan hasil peningkatan seperti yang telah dijabarkan di atas maka dapat disimpulkan bahwa dengan menggunakan model pembelajaran Number Head Together (NHT) dapat membuat mahasiswa PBSI UMKO tertarik terhadap pembelajaran menulis, terutama menulis esai. Dengan model pembelajaran NHT telah terjadi peningkatan yang signifikan terhadap kemampuan menulis esai. Dengan demikian, secara otomatis dosen telah berhasil memberikan motivasi kepada mahasiswa PBSI UMKO. Pembelajaran menulis esai menggunakan kooperatif NHT dapat meningkatkan hasil belajar mahasiswa, hal ini menunjukan bahwa pembelajaran kooperatif NHT efektif untuk diterapkan dalam belajar. Peningkatan hasil belajar menggunakan kooperatif NHT juga terjadi pada penelitian yang dilakukan oleh peneliti sebelumnya tentang efektivitas penggunaan model kooperatif NHT (Setyaningsih \& Utami, 2021; Sri Puji Retno et al., 2021; Wahyuni, 2019).

Peningkatan bukan saja terjadi pada hasil tes mahasiswa dalam menulis esai, tetapi juga terjadi peningkatan lain di luar kemampuan akademik. Seperti kemampuan sikap belajar mahasiswa PBSI UMKO setelah dilakukan pembelajaran dengan model Number Head Together. Mahasiswa menjadi lebih mandiri dan terampil dalam memecahkan masalah dalam proses pembelajaran. Mereka menjadi lebih mandiri dalam mengerjakan tugas, terjalin komunikasi yang baik bukan hanya dengan teman sejawat, melainkan juga dengan dosen. Kondisi pembelajaran pun menjadi semakin menyenangkan sehingga terjadi pembelajaran yang inovatif, kreatif, menyenangkan, dan berbobot, khususnya dalam pembelajaran menulis esai. Kondisi pembelajaran seperti ini sejalan dengan penelitian yang dilakukan oleh (Anse \& Ilham, 2018) bahwa model pembelajran kooperatif NHT dapat menyebabkan respon positif terhadap peserta didik. Hasil pencapaian tersebut dapat diketahui dari perbandingan hasil observasi atau pengamatan, melalui wawancara dengan mahasiswa, dan dokumentasi berupa foto-foto pada saat pelaksanaan pembelajaran dengan model NHT. 


\section{SIMPULAN}

Dari hasil penelitian dan pembahasan yang telah dijabarkan di dalam penelitian ini maka dapat disimpulkan bahwa keterampilan menulis esai mahasiswa semester $\mathrm{V}$ prodi PBSI Universitas Muhammadiyah Kotabumi dengan menggunakan model pembelajaran Number Head Together (NHT) secara signifikan mengalami perubahan ke arah yang lebih baik. Dengan kata lain, mengalami peningkatan perolehan hasil belajar setelah menggunakan model pembelajaran NHT.

Hal itu dapat terlihat dari peningkatan nilai rata-rata kelas yang dicapai mahasiswa. Dimulai dari prasiklus (sebelum penelitian), dilanjutkan dengan siklus I dan siklus II seperti yang telah dijabarkan sebelumnya. Data yang diperoleh tersebut menunjukkan jika hasil menulis esai mahasiswa PBSI mengalami peningkatan yang cukup signifikan. Dari serangkaian uji pada siklus diperoleh data bahwa mahasiswa PBSI dapat dikategorikan dengan nilai yang sangat baik.

Selanjutnya dari hasil observasi melalui wawancara dan dokumentasi selama penelitian didapati hasil yang menunjukkan bahwa telah terjadi juga peningkatan kemampuan belajar mahasiswa PBSI serta sikap belajar mahasiswa PBSI selama pembelajaran berlangsung. Hal itu dapat dilihat dari data pengamatan berupa dokumentasi yang diperoleh dari prasiklus, siklus I, dan siklus II dengan menggunakan/menerapkan model belajar Number Head Together (NHT).

Berdasarkan hasil penelitian ini, dapat diketahui bahwa telah terjadi kenaikan/peningkatan tidak hanya dalam menulis esai, tetapi juga telah terjadi peningkatan motivasi dalam belajar dan hasil belajar mahasiswa PBSI selama mengikuti kegiatan pembelajaran menulis esai dengan model pembelajaran Number Head Together $(N H T)$. Hal ini menunjukkan dampak positif menggunakan model pembelajaran NHT dalam pembelajaran menulis. Pembelajaran model NHT telah mengubah paradigma mahasiswa yang dahulunya menilai pembelajaran menulis esai adalah pembelajaran yang menjenuhkan, kini berubah menjadi pembelajaran yang mengasyikkan dan menyenangkan. Dengan demikian, telah tercipta suasana belajar yang menyenangkan bagi mahasiswa PBSI dan dosen mata kuliah menulis esai.

\section{REFERENSI}

Anse, L., \& Ilham, M. (2018). The Implementation of Cooperative Learning (Numbered Head Together) to Boost Students' Learning Outcome in Social Studies Subject. IOP Conference Series: Earth and Environmental Science, 175(1), 0-4. https://doi.org/10.1088/1755-1315/175/1/012147

Hanifah, N. (2014). Memahami Penelitian Tindakan Kelas: Teori dan Aplikasinya (Julia (ed.)). UPI Press.

Islami, A. I., Budiasih, E., Sukarianingsih, D., \& Sulistina, O. (2021). STAD-NHT vs STAD learning models; the difference in students' achievement on redox reaction. AIP Conference Proceedings, 2330(March). https://doi.org/10.1063/5.0043353

Kosasih. (2012). Dasar-Dasar Keterampilan Menulis. Yrama Widya. 
Núñez Tapia, P. (2012). Writing Competence as an Outcome in Language Teaching Bachelor Degree Programs: A Comparative Analysis in Five Latin American Countries. Revista Complutense de Educación, 23(2), 317-329. https://doi.org/10.5209/rev_RCED.2012.v23.n2.40031

Purnomo, B. H. (2011). Pendahuluan Kedudukan Observasi dalam Tahapan PTK Metode Observasi. Metode Dan Teknik Pengumpulan Data Dalam Penelitian Tindakan Kelas (Classroom Action Research), 8, 251-256. https://jurnal.unej.ac.id/index.php/JP2/article/view/859/673

Rahmawati, N. K., Zaenuri, \& Wardono. (2021). The experimentation of the TTW and the NHT learning models on polyhedron viewed from the problem solving ability. Journal of Physics: Conference Series, 1918(4). https://doi.org/10.1088/17426596/1918/4/042115

Rijali, A. (2019). Analisis data kualitatif. Alhadharah: Jurnal Ilmu Dakwah, 17(33), 8195.

Setyaningsih, N., \& Utami, D. P. (2021). The implementation of the discovery model based on numbered head together reviewed from students' cognitive style in mathematics learning. Journal of Physics: Conference Series, 1722(1). https://doi.org/10.1088/1742-6596/1722/1/012109

Spanou, S., \& Zafiri, M.-N. (2019). Teaching Reading and Writing Skills to Young Learners in English as a Foreign Language Using Blogs: A Case Study. Journal of Language and Cultural Education, 7(2), 1-20. https://doi.org/10.2478/jolace-20190009

Sri Puji Retno, A., Khoiri, N., \& Ihda Norra, B. (2021). The Effectiveness of Cooperative Learning Model in the Type of Numbered Heads Together (NHT) Assisted with Picture Puzzle Media on Self-Efficacy and Student Learning Outcomes in the Coordination System Material. Journal of Physics: Conference Series, 1779(1). https://doi.org/10.1088/1742-6596/1779/1/012058

Sugiyono. (2016). Metode Penelitian Kuantitatif, Kualitatif dan R\&D. Alfa Beta.

Tarigan, H. G. (2013). Membaca sebagai Suatu Keterampilan Berbahasa. Angkasa.

Wahyuni, P. (2019). Implementation of Numbered Heads Together (NHT) type of cooperative learning to improve mathematical communication skills of eighth grade students of YKWI Pekanbaru MTs based on mathematical communication capability indicators. Journal of Physics: Conference Series, 1320(1), 0-8. https://doi.org/10.1088/1742-6596/1320/1/012040

Widoyoko, E. P. (2016). Teknik Teknik Penyusunan Instrumen Penelitian. Yogyakarta. Pustaka Pelajar.

Zahra, F., Zubaidah, S., Mahanal, S., \& Astriani, M. (2021). The improvement of 
students' argumentation skills through Remap-NHT learning model. AIP Conference Proceedings, 2330(March). https://doi.org/10.1063/5.0043291 